\title{
IMPEDIMENTS TO WOMEN HIGHER EDUCATION IN PAKISTAN: A CASE STUDY OF DISTRICT CHITRAL
}

\author{
Ihtisham Uddin \\ Visiting Faculty Member, \\ Department of Political Science, Govt. College University, \\ Punjab, Pakistan \\ Email: ihtishamuddincl@gmail.com
}

\author{
Ahmad Raza Khan \\ Assistant Professor, \\ Department of Political Science, Govt. College University, \\ Punjab, Pakistan \\ Email: ahmadraza@gcu.edu.pk

\section{Fauzia Ghani} \\ Assistant Professor, \\ Department of Political Science, Govt. College University, \\ Punjab, Pakistan \\ Email: fauziaghani@gcu.edu.pk
}

\begin{abstract}
Education is a holistic approach for peace, progress and bringing change in a society. Women equipped with higher education play a significant role in development of a country. The socio-economic and political uplift of a society largely depends on women higher education. Almost all the developed countries of the world give equal attention and consideration to boys as well as girls education; however higher education in underdeveloped states including Pakistan is the most neglected sector. In developing countries including Pakistan one of the major causes of lagging behind economically and socially is absence of technically qualified and highly educated women. Since its inception Pakistan has faced many serious issues in education sector and the education system has failed to deliver to the aspirations of the people. However, literacy rate in Pakistan since 2014 has sustainably increased from 56 percent to 59 percent, however the ratio and proportion of girls is 43 percent as compared to boy's 57 percent which is still a matter of serious concern. The status of women education varies in rural urban division in Pakistan. Situated just across the borders of Afghanistan Chitral is the northern-most district of Khyber Pakhtunkhwa. Because of its topology and geographic location Chitral is isolated from the rest of Pakistan. The socio-economic sector of the area was largely ignored in the past, due to which the living condition of
\end{abstract}


people are extremely poor. Among the population of 4 lakhs almost 36 percent of the population live below the poverty line according to a baseline survey (ICUN). Although the ratio of education in Chitral is high comparatively in Khyber Pakhtunkhwa, but still women face substantial challenges and hurdles in higher education. Women education in primary and secondary level is slightly better than higher education level. Women face many hurdles and issues because of socio-cultural taboos, financial constraints, negative perception of co-education and lack of facilities in in higher education sector. This paper will discuss and highlight the status of women education in Chitral, problem faced by NGOs working for higher education, impediments to women higher education and will suggest recommendation for a better way forward

\section{KEYWORDS}

Women higher education, Chitral, KPK, University of Chitral, Co-education, working of NGOs, Pakistan, Impediments

\section{INTRODUCTION}

Women education around the world is perceived to be one of the important agents of transformation towards peace and prosperity. Most of the developing countries around the world face substantial challenge in education sector. The constitution of Pakistan article 37 says that education is a fundamental right of every human being, but practically there are lots of challenges and hurdle people face in education sector in Pakistan. According to National Education Policy 2017, the enrollment ratio of women has substantially increased from $36.8 \%$ to $47.2 \%$ by 2014 , but still gender inequalities dominate women education and create socio-economic and cultural constraints. Women equipped with higher education play a significant role in the development of a society. The socio-economic and political uplifting of a society largely depends on women higher education. Education is a holistic approach for progress and change in a society. According to a report published by Human Rights Watch in 2018 in Pakistan women face many challenges and hurdles in education sector. Many of these barriers' girls face are within the education system and outside as well. The social liberation, economic development, freedom of choices and development in human capital of nation largely depends on women education.

Chitral district of Khyber Pakhtunkhwa has a unique cultural and social setup. Nearly half of the population comprises of women. Literacy rate in Chitral among women is almost higher compared to other parts of Khyber Pakhtunkhwa. Women still face many challenges and hurdles while receiving higher education. The socio-cultural environment is based on patriarchal values. Man dominates almost every sector of the society. 
This study intends to highlight the status of women in higher education in Chiral, the study will discuss the working of different NGOs in higher education sector of Chitral, the study will also attempt to illustrate problems faced by women in higher education and will conclude with possible and preferable way forward.

\section{REVIEW OF LITERATURE Women education}

According to Nelson Mandela "Education is the most powerful weapon you can use to change the world". Women play a substantial role in the development of a society. Their role and importance can be increased through proper education. The importance of education for women cannot be ignored in any case, education brings awareness in the society as it develops the socio-economic sector of the society. For bringing women to the mainstream of development, education plays a significant role by overcoming the barriers women face in different walks of life. According to a report of UNESCO, worldwide 132 million girls are out of schools. Among them 34.3 million are of primary school age, 30 million of lower secondary level and 67.4 million of upper secondary school age. The ratio of girls in countries with least economic development is twice than countries with stable economies.

One of the greatest needs of the contemporary world is to spread education among women. As a matter of fact, there is room for the extension of education even among men. The condition of women's education is however such that any attempt as it spread deserves help and encouragement from all quarters(Murtaza, 2012).Higher education enables women to understand their rights given in the constitution, it also empowers by imparting knowledge of confidence through which women will be more capable to exercise their responsibilities efficiently (Murtaza, 2012).

Women education enhances the quality and standard of women inside and outside their homes. Women education not only defines how many girls are enrolled in schools but It's about ensuring that girls gain knowledge and feel secure while in educational institutions; have the opportunity and access to complete all levels of education from primary to higher levels, getting knowledge and skills to participate in labor market, learn the socio-economic skills to compete the contemporary world, feel free to decide about their personal matters and contribute in the wellbeing of their family and society (Choudhry, et al., 2019a). Education helps in reduction of inequalities by improving the status and position of women in the society by giving them space and opportunities to participate in the social and development sectors.

\section{Women higher education}

Social progress and development of a nation largely depends on women education. Higher education is considered to be a necessary component of women empowerment. 
The knowledge and expertise communicated through higher education will help change the society towards peace and prosperity.

Higher education increases the capacity for thinking critically, its fosters and increases women participation and inclusion in the development process and provides women the prospects and opportunities to boost their self-confidence and self-esteem (Singh \& Singh, n.d.).Higher education encounters the prevailing social role of women in society, where women mostly remaining inside their homes and only participate in house chores. Higher education deters and discourages these social taboos and opens new role and avenues for women to avail (Saira Zafar Khan, 2015).

Shamran and Afroz in their research have come up with remarks that higher education helps women boosting their confidence and increases their prestige and honour in society, lessens their financial dependency, increases their role in society, expands opportunities and helps in healthier nurture of their off springs (Sharma \& Afroz, 2014). While discussing women social role and participation in society, Benish, Auraj, Nadeem, Bhatti and Nawaz have come up with the conclusion that women decision making power is directly dependent on their education. Educated women have positive level of understanding and participation in the decision-making process of the society, and their education further strengthens their position by cultivating and nourishing gender equality in society (Nawaz et al., 2017). Higher education has substantial benefits for the society as it increases women productivity and their participation in nation building which will catalyze economic and social growth.

\section{Status of women education in Pakistan}

As an Islamic Republic Pakistan got independence from the British Empire in 1947(Pakistan : History | The Commonwealth, n.d.). The administrative, financial and infrastructural sector were very weak since the creation of Pakistan. During the British period the areas constituted in western sides of Indian sub-continent were less developed in education which later became the part of Pakistan.

The first and foremost challenge Pakistan faced since its inception was literacy rate. Almost $90 \%$ of the country were illiterates. Serious steps and practical approach was necessary to counter this issue. While observing the seriousness and significance of education for nation building, soon after independence an advisory board was constituted to set educational policies, and All Pakistan Educational Conference was the primary effort in 1947 to frame and constitute new polices for education, where higher education, and education for women was specifically discussed. With the passage of time new education polices were framed and adopted with the contemporary changing environment and according to the needs of people. 
The constitution of Pakistan clearly highlights that "it's the responsibility of the state to provide free and compulsory education to its citizen in accordance with the law (Constitution, 1973). A new report in 2018 by Human Rights Watch which clearly specifies that 22.5 Million children not enrolled in schools which clearly reflects the backwardness of the society in education sector.

\section{The status of women education in Chitral}

As compared to other parts of Khyber Pakhtunkhwa district Chitral has a high literacy rate. The increase literacy rate is because of the role of private sector in education. Although literacy rate among women in school level is good but there are challenges and hurdles for women in higher education sector.Because of social constraints and cultural taboos education for girls in Chitral is not always welcomed, girl face discrimination and bias as families prioritize boys over daughters (Rakshinda Shah, 2015).

In Chitral women are mostly restricted inside their homes. Women mobility in public places is not a part of their culture. Receiving education for women in very challenging. Families reluctantly permit their daughters for education. Women are always accompanied by male members of the family if they have to go outside (Almina Pardhan, 2005).Women education brings progress and prosperity in a society. Rabia and $A l i$ in their research have highlighted and discussed the importance of women education for their empowerment in Chitral. "education brings clear and visible change in women's lives, yet there are some challenges for those who do not understand the efficacy and they do not understand to utilize it in a meaningful way (Ali \& Ali, 2015). Chitral is an underdeveloped area where women most of the times remain inside their homes. Social rectification and gender discrimination has compelled women to stay indoors and engage in house chores. The status and role of women in society is increasing day by day. But still women face many hurdles and challenges in their educational life. Women in higher education are more vulnerable to socio-cultural and economic constraints.

\section{Challenges to women education in Pakistan}

Saira Ronaq has categorically discussed women issues in Pakistan; the division of labor concise women within the four walls of their houses as women mostly remain indoor engaging in house chores, (Eleven Traits of Pak Culture.Odt, n.d.). The social fabric of the society is based on certain norms and principles where people believe that girls are made only to manage the activities inside homes and therefor, they perceive education for girls is meaningless.

Aisha and Amir believe that in Pakistan women employment is rare. The ratio of women employment is different in rural and urban areas. In rural areas restriction on 
women employment in greater as compared to urban areas, mostly women are not allowed to do job because families consider it dishonor and disgrace (Malik \& Aamir, 2017).Pakistan remains in bottom level with regards to women participation in work force which is less than 51 percent of the world average(Sarwar \& Abbasi, 2013). A report of Global Gender Gap Index presents that; Pakistan remains at no 148 of 149 countries in terms of gender equality, which shows the deteriorated and declined position of Pakistan in gender equality. (Ahmed, 2018).

Mukhtar and Rashid have discussed different issues faced by women in the way of education like; infrastructural challenges, lack of participation of women in education sector, lack of attention of government for educational development, excessive dropout rates in schools etc. (Rashid \& Mukhtar, 2012).Among the challenges faced by women in education sector lack of funds provided for education sector is also of great importance. Funds provided for women education are less than problems faced by women('Lack of Funds a Hurdle to Women's Empowerment' | Pakistan Today," 2012).

Abubakar Nazeer Chaoudhry has categorically discussed women educational issues and challenges. While discussing women socio-cultural challenges he elaborates" Socio-cultural factors have negative implications one women empowerment. Women are denied form educational and health facilities. Social taboos do not allow women to have access to a decent job or employment. Uneducated women are more prone to violence and abuses, mostly families also deprive their daughters from property rights(Choudhry, et al., 2019b).According to a report of Oslo Summit on Education resource distribution in education sector of Pakistan is of a serious concern. The federal government should increase the educational resources of least developed provinces, and the distribution of resources within the provinces is also necessary(Dr. Rabea Malik, 2015).From this part of literature, we perceive that women in in Pakistan face discrimination and hurdles while receiving higher education. Social constraints economic hardships and lack of government support to improve higher education are the prevalent factors which restrict women higher education.

\section{Conceptual framework}

After through study of existing literature on women education and challenges faced by women in higher education, certain themes and subthemes have been identified. These themes and subthemes were used as variables and interview was conducted on the basis of these variables.

\begin{tabular}{llll}
\hline S.No & Writer & Themes & Sub-themes \\
\hline
\end{tabular}




\begin{tabular}{|c|c|c|c|}
\hline 1. & $\begin{array}{l}\text { Dr. Rabia } \\
\text { Malik }\end{array}$ & $\begin{array}{l}\text { Factors affecting } \\
\text { women education }\end{array}$ & $\begin{array}{l}\text { 1. Budget cut in higher } \\
\text { education } \\
\text { 2. Resource distribution issues }\end{array}$ \\
\hline 2. & $\begin{array}{l}\text { Nazeer } \\
\text { Chaoudhry }\end{array}$ & Problems Faced & $\begin{array}{l}\text { 1. Socio-cultural constraints } \\
\text { 2. Violence and abuse against } \\
\text { women }\end{array}$ \\
\hline 3. & $\begin{array}{l}\text { Mukhtar } \\
\text { and Rashid }\end{array}$ & $\begin{array}{l}\text { Impediments for girl's } \\
\text { education }\end{array}$ & $\begin{array}{l}\text { 3. Job employment ratio is low } \\
\text { 1. Infrastructural issues } \\
\text { 2. Financial constraints } \\
\text { 3. Distance of educational } \\
\text { institutions }\end{array}$ \\
\hline 4. & $\begin{array}{l}\text { Aisha and } \\
\text { Amir }\end{array}$ & $\begin{array}{l}\text { Barriers to women } \\
\text { education }\end{array}$ & 1. Domestic issues \\
\hline 5. & Saira Ronaq & Gender Discrimination & $\begin{array}{l}\text { 1. Labor division at homes } \\
\text { 2. House chore burden } \\
\text { 3. Economic constraints }\end{array}$ \\
\hline 6. & $\begin{array}{l}\text { Almina } \\
\text { Pardhan }\end{array}$ & Problems Faced & $\begin{array}{l}\text { 1. Socio-cultural constraints } \\
\text { 2. Religious misconception }\end{array}$ \\
\hline
\end{tabular}

\section{RESEARCH METHODOLOGY}

Earlier version of these data was used in an unpublished MPhil thesis of the researcher in Department of Political Science, Government College University Lahore,The study is based on primary as well as secondary data. Primary data were collected through interviews. Semi structured questions were prepared and interviews were conducted by the researchers in University of Chitral, Human Rights Commission Chitral, Women Empowerment Centre Chitral, NGOs working in Chitral and informal discussions about educational issues with students of University of Chitral.

\section{Data Collection}

This study was conducted at University of Chitral. Earlier version of these data was used in an unpublished MPhil thesis of the researcher in Department of Political Science Government College University Lahore. The targeted population for interviews were old and recently studying students of University of Chitral. Data were collected from Admission Section Registrar office, Transport Management Section, Provost Office, and Hostel Management Section. This was an indigenous research and semi-structured interviews were conducted by taking variables from literature. Interviews were conducted from Human Rights Commission Chitral (HRCC), Agha Khan Education Service (AKES) ROSE Foundation Chitral, Alkhidmat Hostel Facilitation Centre Chitral, Women Empowerment Centre Jughoore Chitral and currently enrolled students were included through formal and informal discussions. 


\section{FINDING \& DISCUSSION}

After analyzing literature and collecting data through interviews and discussions the researchers have highlighted certain factors which deter women higher education in Chitral;

\section{Socio-cultural constraints}

In order to tackle the contemporary challenges in social, political and economic field importance and utility of women as human resource can never be ignored. In Pakistan women are almost 50 percent of the total population, their presence and support for the upliftment of society is very essential.

Unfortunately, in Chitral, social fabrication and gender discrimination in society has compelled women to remain indoor and participate only in house chore. Socio-cultural constraints have weakened the status of women in the society. "Families are less concerned about girl's education and more concerned about their marriages. Girls are usually not encouraged to be social. "Families usually encourage their daughter to study in school level but unfortunately, they do not give preference to their higher education (Interview quote, Chairman ROSE).Because of the existence of gender disparity women face issues and challenges in almost every sector, the presence and participation of women in social sector is increasing day by day, but still there are many difficulties women face. Women must be considered as an entity in the society and human rights are applicable on male and female members equally but the society always prioritizes boys over girls.

Chairman Human Rights Commission Advocate Niazi A Niazi believes that; "Among the factors affecting women higher education in Chitral socio cultural factors excessively disturb and distract women education; House chore burden, early marriages, joint family system and prioritization of boys over girls are the dominant factors which discourage women higher education"

"Girls' early marriages also prevent their empowerment as women will be bound and subjugated after marriage. Economically dependent women spend more miserable life as compared to women who are engaged in any kind of job or employment" (Interview quote AKDN staff).Labor division at homes has infuriated women distress and anxiety as household burden lessens their participation in social and societal affairs. "Sociocultural constraints, early marriages of girls, women harassment at workplaces, house hold burden, lack of awareness about the utility of education have aggravated the miseries of women in Chitral especially young girls. The consequences of these deprivation end in divorce or suicides, which is prevalent excessively among young girls in Chitral" (Interview Quote, Chairman HRCC). 


\section{Views of a student;}

"I get up early in the morning at 4 am, we live in a joint family, I am mother of two sons. My daily routine is to manage all the affairs of the house from grazing cattle's, milking cows, preparing breakfast washing and pressing cloths of my husband and my children. At 8 am morning I get myself ready to University, I get back at $2 \mathrm{pm}$ from university and prepare lunch for my entire family, I even have no time to take nap. Managing the household duties is my never-ending daily routine which I can hardly manage with my higher education" (Interview quote Student of UOC).

Some reflections of the old students of University of Chitral. "I am Safia (pseudonym) from Chitral. We are 16 members in our family. My father is a retired teacher. I was very intelligent and bright student when I was at school. I studied in co-education system at school level. When I passed my matric examination, my family allowed me to study in college and I was admitted in a private college which was only for girls. After my college education I faced many issues and challenges for my higher education. The first and foremost challenge I faced was; my family was not willing to let me study further but I was enthusiastic for higher studies. Instead of higher education my family was more concern about my marriage. Since I belong to upper Chitral and there were no higher education facilities, my family reluctantly permitted to study in university. When I was studying in M.Sc. Previous class I was asked to marry which I accepted without any hesitation because there were no other options for me. I completed my higher studies thereafter. After graduation it was difficult for me to convince my in-laws for job. Now I am working with NGOs in my local area on minimum wages because my family did not allow me to do job in another village or city. (Interview on April 2,2020).

Another Student of University of Chitral continued, "I am Rafia (pseudonym) from Torkhow Chitral. Presently I am working as a primary teacher in a government school. In Chitral women face many hurdles and obstacles while receiving higher education. The difficulties faced by women are much higher as compared to boys. My family told me to marry with a boy when I was at class $9^{\text {th }}$. I accepted the offer because I was too immature to understand the prospects of early marriages. Luckily my in-laws were educated but still social taboos and cultural norms were obstacle in my educational life. It was difficult for my family to allow me study in co-education because there was no separate university for girls. My family allowed me to study in higher education with great difficulties. Managing household with higher studies was very challenging for me. I was brilliant in studies and was expecting a decent job in administrative offices but because of household burden and socio-cultural taboos I could not achieve my desired goal. My family has allowed me to do job as a teacher in school which is $4 \mathrm{~km}$ away from my home and it's very difficult for me to manage house chore with my job" (Interview 28 March, 2020).Another girl currently studying in higher 
education said; I am Rabia (pseudonym) currently studying in higher education in University of Peshawar. I was studying in co-education system with my two elder brothers when I was in School. On daily basis we travel almost 50 mints by foot to reach school. When I passed my $10^{\text {th }}$ class exam my family insisted me to study in a Madra which was in our own village, and my family was not willing to allow me to study in College. They thought that allowing a girl to study in a college was against socio-cultural norms and investing on women education is wastage of money, while my two-brother got admission in a government college which was almost $200 \mathrm{Km}$ away from our village. I was brave enough to challenge the social taboo and insisted to study further in college level. My family reluctantly permitted me to study in college which I completed in 4 years with high grades, after college education it was another challenge for me to convince my family for higher education but instead of higher education family was thinking about my marriage prospects. Fortunately, I was able to get admission in University of Peshawar. Now I am about to graduate and my long walk did not end here as I have ambitions to study up to PHD level" (discussion of April 4 2020).

After analyzing and interpreting the existing data and comparing it with literature it is obvious that certain factors directly and indirectly hinder women higher education like Gender discrimination, negative perception of the society and families towards higher education, early marriages of girls, societal interference, household burden. These issues and challenges can be tackled through proper mechanism at social and familial level. The role of media is necessary to highlight these issues. NGOs with the collaboration of government can also play substantial role in discussing women issues and highlighting their role in society.

\section{Lack of facilities for higher education}

Chitral is a least developed area where infrastructural development is very weak. For higher education the only public sector university was established in 2017. University of Chitral is located at the distance of almost $10 \mathrm{~km}$ away from City Chitral. Lack of educational facilities and infrastructural issued aggravate the situation for higher education. The newly established university faces financial constraints. The building allocated for university was used as Agriculture Project Building before it was a university and the newly established university was shifted there. The facilities inside university are not enough to meet the requirements of higher studies.

After formal and informal discussions with the university faculty the researcher identified certain issues which create lots of problem and difficulties for example; lack of hostel facilities for women, lack of residential facilities for male and female teachers, transport system is not well developed, there are no internet services except on specific locations, there is no separate common room and library for students, there 
is no student facilitation Centre (interview quote, staff UOCH).Learning facilities have direct effect on the performance and creativity of students. In Pakistan generally and In Chitral specifically because of unavailability of proper educational facilities the grooming and development of students in inversely affected. A suitable environment will be more beneficial in boosting the student's performance and will create new avenues and doors for their development and progress.

\section{Government least attention towards higher education}

For the efficient and smooth working of every department and institution the interest of government is necessary. It's the responsibility of state to provide education facilities to their citizens. Unfortunately, in Pakistan generally and in Chitral particularly lack of government attention towards education has aggravated the social deprivation.

While addressing the negligence of government in education sector HRC commission Chairman Advocate A Niazi said that;

"Government has increased the educational expenditures for higher education which is almost intolerable for families with limited incomes. University of Chitral faces financial crisis, government did not provide grants for newly established universities. There is no proper infrastructure of University, University did not provide proper boarding facilities for female teacher and students. Weather is Chitral remains severely cold in winter and there is no proper central heating system inside university, there are no internet facilities for students (Interview conducted on $5^{\text {th }}$ April 2020).

To provide quality of life and to enhance social sector, infrastructure has a paramount significance. District Chitral is a least developed area with small scale development in infrastructural sector. Chitral is a mountainous area were travelling from one side to another sometimes takes so many hours. University of Chitral was established in 2017, before this University there were no other higher education facilities in Chitral. The university is located at a distance of almost $9 \mathrm{~km}$ away from city area. "Travelling to university almost takes 40 to 50 mints for those students who directly come from their homes. In Chitral summer are short but winter are long and extreme. Travelling to university in winter is more challenging. Lack of proper transport system and deteriorated conditions of road more intensify the problem. Women who participated in this study were well aware of the issues and challenges they face while travelling to University;

"Going to university is very difficult in winter, poor management of roads lack of proper transportation and lack of central heating system inside university are the difficulties student face in higher education. Beside that our transportation system is not as much efficient, sometimes our buses collapse and breakdown on roads and we travel by foot or an alternate bus is arranged for us (Interview quote, student). 
Beside issue and challenges faced by women on roads and university women also face difficulties and issues in finding accommodation facilities. Almost 50 percent of girls live in hostel for higher education in Chitral. "University of Chitral has a single registered private hostel for girls which is not enough to accommodate the increased number of students" Interview quote, staff member of UOCH).

The chairman Human Rights Commission elaborated further;

"There are no residential facilities for female teachers also. There are also lack of private hostels for girls in City Chitral, therefore most of the women coming from farflung areas adjust with relatives or they hire private rooms on rent where they face difficulties like; electricity and gas shortage, scarcity of water, internet issues etc. (Interview quote, Advocate Niazi A Niazi, Chairman HRCC).

\section{Financial constraints}

Among the issues faced by women in higher education, financial issues are very serious one. In Pakistan the increased financial expenditures in higher education have heavily affected the students. Students are the most underprivileged class of the society, increased higher education expenditures has largely infuriated their deprivation in education sector. Universities all over Pakistan are facing enormous pressure because of budget cuts in higher education. The federal government has levied a huge cut of 37 percent to the higher education development budget. The budget cut directly affects the students who are the real stack holders. Increased higher education expenditures infuriates the financial constraints for students as mostly people in Pakistan work on daily wages who could not afford the influx of financial burden.

"My father is a retired scout officers who earns a pension of 17 thousand per month, we are 8 members in our family and are all dependent on my father's income. It was impossible for me to manage my higher education expenses although I was willing to get admission in higher education. my father took a loan from bank and I got admission in University, I can hardly manage my higher education expenditures" (Interview quote, University Student).

People in Chitral are mostly poor. Majority of people work on small agricultural lands through which they can hardly maintain their household expenses. Providing higher education for their children is very challenging for them.

\section{NGOs lack support}

For better social development and smooth working of different institution the role of private sector is very necessary. Private sector will work hand to hand with government sector to cooperate and to remove the deficiencies and to fill the vacuum created by public sector. In Chitral different NGOs are working separately and with collaboration 
of government sector in different sectors like; health, education, poverty alleviation etc. Private sectors like Agha Khan Development Network (AKDN), Sarhad Rural Support Program (SRSP), Regional Organization for Supporting Education (ROSE) etc. are working in different areas like, Mastuj, Khot, Rech, Mulkhow, Melp etc.NGOs working in Chitral have dissent and apprehension that government is not providing support and assistance for them.

"Lots of NGOs have come to Chitral willing to work for women empowerment and have left saying that government is not supporting them and they are hesitant to invest" (Interview quote Chairman HRCC).

"Socio-cultural taboos and religious misconception and financial problems for NGOs are the barriers which private sectors themselves face, we intend to highlight women problems and issues but instead we ourselves face socio cultural taboos" (Interview quote, member of private sector).Women Empowerment Center Chitral is been established to help girls in education and acquiring skills like embroidery, teaching tailoring, helping girls in IT and teaching Quran recitation. The interviewer discussed about the issue faced by women with a staff member and she highlighted "We face administrative issues lack of transportation for staff and students, poor management and infrastructural issues and lack of resources and funds" (Interview quotes staff member).

Survey results and interview indicate that NGOs working in Chitral for women empowerment face difficulties and problem while delivering services to the community. NGOs are working in those areas where the approach and access of government sector is very least. For better working and efficient service delivery in social sector NGOs need support and assistance from the government sector and civil society. The local community should also play their role to assist and support the NGOs so that they could work efficiently and creatively.

\section{Misconceptions about Co-education system}

Co-education system is exercised almost everywhere in the world. In Pakistan coeducation system is also adopted in private and public educational institutions, but there are also separate universities for boys and girls. Mostly universities in Pakistan have co-education system.

Co-education system helps both boys and girls to interact with each other which will increase their self-confidence in practical life. Through co-education system one can increase their interaction and communication methods and it reduces the hesitation (Dawn, 2009).

Some reflection of students about co-education system; 
"When I was to get admission in higher education my family reluctantly allowed me to study in co-education. There was no other option because there was no separate university for girls in Chitral. Personally, I do not face any difficulties and problems in co-education system instead co-education system boosts our self-confidence and enhances social maturity. Traditional mind setup of our families has compelled them to abstain girls to study in co-education while my two elder brothers also study in coeducation and my family has no problem with that".

Although co-education system is a universally accepted phenomenon but in Chitral because of socio-cultural setup people do not like co-education. In 2017 University of Chitral was established with a system of co-education. Families mostly prefer separate universities for their daughter but because there are no other alternatives therefore, they reluctantly allow their daughters to study in university.

\section{House chore burden}

Receiving higher education and managing household affairs is a very tough task. Higher education needs serious attention and determination for its accomplishment. In Chitral labor division has compelled women to remain indoor and engage in household. Women face very rough time while managing household affairs especially those families who have joint family system.

Sabia (pseudonym) is a student of UOC she says,

"Managing household with my higher education is very challenging for me. After getting back from university I have lots of works to do at home. Washing clothes, preparing food, grazing cattle's, collecting fire woods and bringing water are my daily activities. Some times because of household burden I even miss my classes. I have very rare time at home for studies, the rest of time I spend on house chores"

For higher education it is necessary for families to accommodate their daughters by reducing their home responsibilities. Laghli Jahan an old student of UOCH says "I was mother of a daughter when I was studying in higher education. It was a very difficult job for me to take care of my child and to manage my studies. I was not only taking care of my child but all the household affairs were on my shoulders" (Interview quotes, 4 April 2020).

\section{CONCLUSION}

In conclusion we can analyses that; higher education for women is as obligatory as for man. Higher education is perceived an effective tool for development and social change. Unfortunately, in Pakistan girl's education is extremely undervalued. This paper demonstrates the different impediments and problems which affect women higher education in Chitral. 
The study clarifies that lack of government support and socio-cultural constraints have directly and indirectly affected women higher education. Although different NGOs and community-based organizations are working for the development and enhancement of women education but still there is need of practical steps and substantial measures to be adopted to curtail the issues faced by women in higher education.

\section{RECOMMENDATIONS}

After studying and analyzing the status of women higher education and problem faced by women in their higher education certain recommendations are suggested; The government must increase the funding of higher education, especially those universities which are newly established so that education can be affordable to everyone. Steps must be taken by NGOS and Government sector to increase participation of women in higher education through different strategies by arranging community based work-shops in far-flung areas highlighting women issues and their rights to education. A national cohesion and strategy is necessary to make national action plan to stop and end child marriages so that women can easily access higher education. University of Chitral must be updated by providing basic educational facilities like internet, library, hostel facilities, proper transport facilities and more faculties must be introduced by establishing MPhil and PHD classes Government must increase and strengthen child labor polices so that girls engaged in paid and unpaid labor can have more opportunities to higher education.

\section{REFERENCES}

Ahmed, A. (2018, December 19). Pakistan among worst performers on gender equality: WEF [News Paper]. DAWN.COM. https://www.dawn.com/news/1452284

Ali, R., \& Ali, M. (2015). Education and Women'S Empowerment in Northern Pakistan: Tracing Accomplishments and Predicaments. 12.

Almina Pardhan. (2005). Booni Valley Women,s Perceptions of Schooling: Hopes and Barriers. International Education Journal, 6(4), 438-445.

Choudhry, A. N., Mutalib, R. A., \& Ismail, N. S. A. (2019a). Socio-Cultural factors affecting Women Economic Empowerment in Pakistan: A Situation Analysis. Human

Resource Management Academic Research Society (Www.Hrmars.Com), 9(5), 90102. zotero. https://doi.org/DOI: 10.6007/IJARBSS/v9-i5/5842

Choudhry, A. N., Mutalib, R. A., \& Ismail, N. S. A. (2019b). Socio-Cultural factors affecting Women Economic Empowerment in Pakistan: A Situation Analysis. Human Resource Management Academic Research Society (Www.Hrmars.Com), 9(5), 90102. zotero. https://doi.org/DOI: 10.6007/IJARBSS/v9-i5/5842

CONSTITUTION OF THE ISLAMIC REPUBLIC OF PAKISTAN, 1973. (1973, August 14). Pakistan Constitution. https://pakistanconstitutionlaw.com/

Dawn. (2009, September 5). View point: The two sides of co-education. Dawn. dawn.com/news/884867/view-point-the-two-sides-of-coeducation 
Dr. Rabea Malik. (2015). Financing Education In Pakistan [Education for Development]. University of Cambridge. reliefweb.int/sites/reliefweb.int/files/recources/pakista.pdf Eleven traits of pak culture.odt. (n.d.).

'Lack of funds a hurdle to women's empowerment' | Pakistan Today. (2012, March 9). Pakistan Today. https://www.pakistantoday.com.pk/2012/03/09/\%E2\%80\%98lackof-funds-a-hurdle-to-women $\%$ E2\%80\%99s-empowerment $\%$ E2\%80\% $\% 9 /$

Malik, D. A. A., \& Aamir, M. (2017). HURDLES IN WOMEN DEVELOPMENT IN PAKISTAN. Margala Papers, 12.

Murtaza, K. F. (2012). Women Empowerment Through Higher Education in Gilgit Baltistan. International Journal of Academic Research in Business and Social Sciences, 2(9), 343-367. Zotero.

Nawaz, M., Ramzan, B., Nadeem, M., Bhatti, G. A., \& Nadeem, A. (2017). The Influence of Higher Education in Improving Women,s Social Status: An Empirical Evidence

From Lahore,Pakistan. International Journal of Research Granthaalayah (A Knowledge Repository), 5(7). oaji.net/articles/2017/1330-1507022006.pdf

Pakistan: History| The Commonwealth. (n.d.). Retrieved January 2, 2020, from https://thecommonwealth.org/our-member-countries/pakistan/history

Rakshinda Shah. (2015). Interpretations of Educational Experiences of Women in Chitral, Pakistan. Graduate Theses and Dissertations., 95. Zotero.

Rashid, Dr. K., \& Mukhtar, S. (2012). Education in Pakistan: Problems and their Solutions. International Journal of Academic Research in Business and Social Sciences, 2(11). Zotero.

Saira Zafar Khan. (2015). Higher Education for Women: A self Empowerment and Gender Perspective. Pakistan Institute of Development Economics.pride.org.pk/pdf/ DevStudies/workingpaper/DS_WorkingPaper1.pdf

Sarwar, F., \& Abbasi, A. S. (2013). An In-Depth Analysis of Women's Labor Force Participation in Pakistan. Middle-East Journal of Scientific Research, (IDOSI Publications, 15(2), 8. Zotero. https://doi.org/0.5829/idosi.mejsr.2013.15.2.2367

Sharma, R., \& Afroz, Z. (2014). Women Empowerment Through Higher Education. International Journal of Interdisciplinary and Multidisciplinary Studies, 1(5), 1822.

Singh, S., \& Singh, H. (n.d.). EDUCATION AND WOMEN EMPOWERMENT. 6(11), 6. UNICEF. (n.d.). Girls Education Gender equality in education benefits every child [Girls Education]. United Nations. unicef.org/education/girls-education 